\title{
Demographic characteristics and neurological comorbidity of patients with COVID-19
}

\author{
Türkan Acar ${ }^{1}$ \\ Dilgehan Atılgan Acar ${ }^{1}$ \\ (iD) Yeşim Güzey Aras ${ }^{1}$ \\ (iD)Turan Doğan ${ }^{1}$ \\ (iD) Sena Boncuk ${ }^{1}$ \\ (iD) Halil Alper Eryılmaz ${ }^{1}$ \\ (iD) Nimet Can ${ }^{1}$ \\ (i) Yusuf Can ${ }^{1}$
}

\section{SUMMARY}

ABSTRACT: The COVID-19 infection that started in the Wuhan Province of the People's Republic of China and has now spread throughout the world is not limited to the respiratory system, but also causes other systemic symptoms through viremia. Recent data show that the central and peripheral nervous system involvement is particularly substantial. Thus, the present study aims to investigate the current neurological comorbidities and symptoms of patients with COVID-19 who were followed up by our clinic physicians.

KEYWORDS: Coronavirus Infections. Comorbidity. Neurologic Manifestations.

\section{INTRODUCTION}

The disease, named "new coronavirus disease" (COVID-19), which first appeared in December 2019, has rapidly spread from the Wuhan province of the People's Republic of China to other provinces and then all over the world 1 . Coronaviruses are single-stranded, positive polarity, enveloped RNA viruses with rodshaped protrusions on their surfaces in a roughly spherical and pleomorphic form, which is about $125 \mathrm{~nm}$ in diameter ${ }^{2}$. It is known that these virus infections are highly contagious, transmitted from person to person, and from contaminated surfaces ${ }^{3}$. The effects of the COVID-19 infection are not only limited to the lungs but can cause other symptoms through viremia after the virus enters the body. In COVID-19 patients, fever, dry cough, and fatigue are the primary symptoms; in some patients, sore throat, chest tightness, sputum, loss of appetite, abdominal pain, diarrhea, vomiting, and conjunctivitis are also observed. It can be difficult to differentiate COVID-19 from other respiratory diseases ${ }^{4}$. In some groups of patients, neurological symptoms are observed without any respiratory system symptoms ${ }^{5-7}$. Researchers have detected the coronavirus nucleic acid component in patients' CSF analyses ${ }^{8}$. Neurological involvements 
have also been supported by case reports in the literature. Several neurological symptoms, including central nervous system (CNS) involvement, peripheral nervous system (PNS) involvement, and skeletal muscle damage, were reported in more than a third of patients ${ }^{6}$. In this study, the demographic data of the COVID-19 patients followed-up in our clinic and their neurological comorbidities were investigated in detail.

\section{METHODS}

The patients with COVID-19 followed-up at the Sakarya University Training and Research Hospital Neurology Clinic in April 2020 were retrospectively investigated. Patients in the 18-100 age group with a COVID-19 diagnosis, who presented any symptoms, were included in the study. All the neurological and non-neurological symptoms of the patients were classified.

\section{Ethics Committee Approval}

Approval was received from the Ethics Committee of the Faculty of Medicine of the Sakarya University.

\section{RESULTS}

The study was conducted with a total of 30 patients, of which $13(43.3 \%)$ were male and $17(56.7 \%)$ were female, followed by the diagnosis of COVID-19. The age range of the patients was 26-91 (average of 51.6 years). Of the patients, 28 (93.3\%) were hospitalized for treatment (Table 1).

In the examination of the neurological and non-neurological comorbidity information from the patients' histories followed by COVID-19 diagnosis, $8(26.7 \%)$ patients had hypertension (HT), 6 (20\%) had diabetes mellitus (DM), 3 (10\%) had coronary artery disease (CAD), 1 (3.3\%) had chronic renal failure (CRF), 1 (3.3\%) had Parkinson's disease, 1 (3.3\%) had restless leg syndrome (RLS), 3 (10\%) had cerebrovascular disease (CVD), 1 (3.3\%) had renal transplantation, and 1 (3.3\%) patient had polyneuropathy (Table 2).

According to the neurological and non-neurological presentation of symptoms, distribution by gender, and the average age of the patients followed-up after the COVID-19 diagnosis, fever was present in a total of 23 patients, of which 10 were male, and the average age was 48.7. Cough was present in 11 patients in total, of which 5 were male, and the average age was 54.6 . Shortness of breath was found in 10 patients, of which 6 were male, and the average age was 52.6. Myalgia was found in 15 patients, of which 5 were male, and the average age was 52.7. Headache was found in 10 patients in total, of which 5 were male, and the average age was 42.4. Dizziness was only present in 3 female patients, and the average age was 40 . Diarrhea was only present in 3 female patients, and the average age was 44.6. Nausea and vomiting were found in 2 female patients, and their average age was 48. CVD comorbidity was detected in 2 female patients with COVID-19, and their age average was 58 . Fatigue was present in 11 patients in total, of which 4 were male, and the average age was 51.1. Anosmia was present in 10 patients, of which 5 were male, and the average age was 44.9. Syncope was found in 1 male patient, and his age was 38 . Delirium was present in 4 patients, of which 3 were male, and the average age was 78.2 (Table 3 ).

The time between the onset of symptoms and hospital admission was in the range of 1-10 days, and the average was 3.4 days. The time from the start of the treatment to discharge was in the range of 3-28 days, and the average was 8.5 days (Table 3 ). During the treatment, 2 patients died.

For the treatment, all the patients received hydroxychloroquine, $60 \%$ received oseltamivir, $80 \%$

TABLE 1. DEMOGRAPHIC DATA OF PATIENTS FOLLOWED UP DUE TO COVID-19 DIAGNOSIS

\begin{tabular}{l|l} 
Demographic data & $\mathrm{n}(\%)$ \\
\hline Total & 30 \\
\hline Age (age range, average) & $26-91(51.6)$ \\
\hline Gender & \\
\hline Male & $13(43.3)$ \\
\hline Female & $17(56.7)$ \\
\hline Inpatient treatment & $28(93.3)$ \\
\hline
\end{tabular}

TABLE 2. COMORBIDITY INFORMATION OF PATIENTS FOLLOWED-UP DUE TO COVID-19 DIAGNOSIS

\begin{tabular}{l|l} 
Comorbidity & $\mathrm{n}(\%)$ \\
\hline $\mathrm{HT}$ & $8(26.7)$ \\
\hline DM & $6(20)$ \\
\hline CAD & $3(10)$ \\
\hline CRF & $1(3.3)$ \\
\hline Parkinson's disease & $1(3.3)$ \\
\hline RLS & $1(3.3)$ \\
\hline CVD & $3(10)$ \\
\hline RENAL TRANSPLANTATION & $1(3.3)$ \\
\hline PNP & $1(3.3)$ \\
\hline
\end{tabular}

HT: Hypertension; DM: Diabetes Mellitus; CAD: Coronary Artery Disease; CRF Chronic Renal Failure; RLS: Restless Leg Syndrome; CVD: Cerebrovascular Disease; PNP: Polyneuropathy. 
received azithromycin, $20 \%$ received favipiravir, and $60 \%$ received enoxaparin (Table 4 ).

\section{DISCUSSION}

The SARS-CoV-2 virus is a member of the Betacoronavirus genus, known for its neurological invasive potential. The virus is able to enter the cell by binding to the Angiotensin-converting enzyme 2 (ACE2), which acts as a receptor. It is present in many tissues in the human body, including the ACE2 nervous system and skeleton muscle. The expression of ACE2 in the nervous system and skeletal muscles may explain some of the neurological features that have been reported so far ${ }^{9-11}$. A cytokine storm, a well-known immune reaction to this viral infection, can lead to the inflammation of the central nervous system $(\mathrm{CNS})^{12}$.

TABLE 3. NEUROLOGICAL AND NON-NEUROLOGICAL PRESENTATION OF SYMPTOMS, DISTRIBUTION BY GENDER, AND THE AVERAGE AGE RANGE IN PATIENTS FOLLOWED-UP DUE TO COVID-19 DIAGNOSIS

\begin{tabular}{l|l|l|l} 
Symptom & $(\mathrm{n})($ male $n)$ & $(\%)$ & $\begin{array}{l}\text { Average } \\
\text { age }\end{array}$ \\
\hline Fever & $23(10)$ & $(76.6)$ & 48.7 \\
\hline Cough & $11(5)$ & $(36.7)$ & 54.6 \\
\hline Shortness of breath & $10(6)$ & $(33.3)$ & 52.6 \\
\hline Myalgia & $15(5)$ & $(50)$ & 52.7 \\
\hline Headache & $10(5)$ & $(33.3)$ & 42.4 \\
\hline Dizziness & $3(0)$ & $(10)$ & 40 \\
\hline Diarrhea & $3(0)$ & $(10)$ & 44.6 \\
\hline Nausea-Vomiting & $2(0)$ & $(6.7)$ & 48 \\
\hline CVD & $2(0)$ & $(6.7)$ & 58 \\
\hline Fatigue & $11(4)$ & $(36.7)$ & 51.1 \\
\hline Anosmia & $10(5)$ & $(33.3)$ & 44.9 \\
\hline Syncope & $1(1)$ & $(3.3)$ & 38 \\
\hline Delirium & $4(3)$ & $(13.3)$ & 78.2 \\
\hline The period from the onset of the & Min-max & & Avg: \\
\cline { 2 - 4 } symptom to admission & $1-10$ & & 3.4 \\
\hline Time of discharge after treatment & $3-28$ & & 8.5 \\
\hline
\end{tabular}

TABLE 4. TREATMENT OPTIONS FOR PATIENTS FOLLOWED-UP DUE TO COVID-19 DIAGNOSIS

\begin{tabular}{l|l|l|l} 
Treatment option & $\mathbf{n}($ male $\mathrm{n})$ & $(\%)$ & Average age \\
\hline Oseltamivir & $18(7)$ & $(60)$ & 47.7 \\
\hline Hydroxychloroquine & $30(13)$ & $(100)$ & 51.6 \\
\hline Azithromycin & $24(10)$ & $(80)$ & 53.1 \\
\hline Favipiravir & $6(3)$ & $(20)$ & 50.8 \\
\hline LMWH & $18(5)$ & $(60)$ & 58.8 \\
\hline
\end{tabular}

LMWH: Low-molecular-weight heparin
The process of neurological involvement in COVID19 can be analyzed in three parts; 1) neurological characteristics of the viral infection; 2) neurological complications after infection; 3) infection in patients with neurological comorbidities ${ }^{13}$. In our study, current neurological symptoms and neurological comorbidity in patients were investigated in the active period of the virus. The neurologic symptoms that we could detect in patients of our clinic were headache, dizziness, anosmia, myalgia, CVD, and delirium. One of the most important details that drew attention in our results was that neurologic symptoms, including headaches, dizziness, and anosmia were more common in patients under the average age of 45 . In particular, the occurrence of headaches in younger COVID-19 patients has a similarity with the mechanisms that explain frequent primary headaches in young people, which could be a separate research topic. Another important issue is that CVD, delirium, and the deterioration of the overall condition was more common in patients over the age of 55 in both groups. This may be due to the increased risk factors in patients of this age group.

In a retrospective study conducted by Mao et al. ${ }^{14}$, the most frequent causes of neurological presentation were dizziness, headache, and anosmia. In our cases, the incidence of headache and anosmia was found to be $33.3 \%$, whereas the incidence of dizziness was $10 \%$.

In another study by Chen et al. ${ }^{15}$, the rate of loss of consciousness among patients who died was $22 \%$, while this rate was $1 \%$ among the survivors. Among our patients, the number of patients with delirium and linked deterioration of the overall condition was 13.3 , and one of these patients died on the $11^{\text {th }}$ day, under treatment.

Common microvascular thromboses develop as a result of prothrombotic activation along with cytokine increase in COVID-19 infection, and D-dimer levels are high in these patients. In the new guidelines by the AHA $/ \mathrm{ASA}^{16}$, it is emphasized that stroke is observed in $5.9 \%$ of the patients, 10 days after the onset of the symptoms in COVID-19. In addition, the first observations are that cerebrovascular diseases are often seen in the group of COVID-19 patients with poor prognosis $^{17}$. Indeed, in our study, 2 patients had acute CVD, and one patient died on the $5^{\text {th }}$ day of treatment.

Fever, cough, shortness of breath, and myalgia are among the most common of COVID-19 symptoms. In a comparative analysis of the coronavirus family, the incidence of myalgia secondary to COVID-19 was 
found as $14.8 \%$, and myalgia incidence was found to be $50 \%$ in our study ${ }^{18}$.

Worldwide, medical practices are carried out in extraordinary conditions during the pandemic. In Turkey, providing the most suitable treatments for our conditions should be our main goal ${ }^{19}$. All the inpatients who were treated received a full dose of hydroxychloroquine. Other treatment options, such as oseltamivir, azithromycin, or favipiravir, were administered as a combined therapy for appropriate patients with additional comorbidity.

\section{CONCLUSION}

Although the COVID-19 pandemic is currently starting to lose its momentum, the risk of a new potential increase is likely to remain on our agenda for a long time. Given the current studies and meta-analyses, it is observed that the rates of neurological involvement in COVID-19 are significant, in addition to the respiratory system involvement. So we presented the data that we think might be particularly useful to neurologists in this study. We believe that the additional data will help with the fact that neurological involvement is substantial and more diverse.

There is no conflict of interest or financial support in the article.

\section{Author's Contribution}

Türkan Acar - Main concept, data collection, writing of the article; Bilgehan Atılgan Acar - Main concept, data collection; Yeşim Güzey Aras, Turan Doğan - Data collection, analysis of the findings; Sena Boncuk, Yusuf Can - Analysis of the findings, resource access; Halil Alper Eryılmaz, Nimet Can - Writing of the article, resource access.

\section{RESUMO}

RESUMO: A infecção de COVID-19 que começou na província de Wuhan, na República Popular da China, e já se espalhou por todo o mundo não se limita ao sistema respiratório, mas também causa outros sintomas sistêmicos através de viremia. Dados recentes mostram que seus efeitos no sistema nervoso central e periférico são particularmente significativos. Assim, o presente estudo tem como objetivo investigar as atuais comorbidades e sintomas neurológicos de pacientes com COVID-19 que foram acompanhados pelos médicos da nossa clínica.

PALAVRAS-CHAVE: Infecções por Coronavirus. Comorbidade. Manifestações Neurológicas.

\section{REFERENCES}

1. Çalişmasi BK. COVID-19 (SARS-CoV-2 Enfeksiyonu) Rehberi. Ankara: TC Sağlık Bakanlığı; 2020.

2. Fehr AR, Perlman S. Coronaviruses: an overview of their replication and pathogenesis. Methods Mol Biol. 2015;1282:1-23.

3. Pascarella G, Strumia A, Piliego C, Bruno F, Buono RD, Costa F, et al. COVID-19 diagnosis and management: a comprehensive review. | Intern Med. 2020;10.1111/joim.13091.

4. Li T, Lu H, Zhang W. Clinical observation and management of COVID-19 patients. Emerg Microbes Infect. 2020;9(1):687-90.

5. Ozturk S. COVID-19 and neurology. Turk | Neurol. 2020. DOI:10.4274/tnd. galenos.2020.73384

6. Mao L, Wang M, Chen S, He Q, Chang J, Hong C, et al. Neurological manifestations of hospitalized patients with COVID-19 in Wuhan, China: a retrospective case series study. medRxiv 2020. doi: https://doi.org/10.11 01/2020.02.22.20026500.

7. Wang D, Hu B, Hu C, Zhu F, Liu X, Zhang J, et al. Clinical characteristics of 138 hospitalized patients with 2019 novel coronavirus-infected pneumonia in Wuhan, China. JAMA. 2020;323(11):1061-9.

8. Lau KK, Yu WC, Chu CM, Lau ST, Sheng B, Yuen KY. Possible central nervous system infection by SARS coronavirus. Emerg Infect Dis. 2004;10(2):342-4.

9. Jin Y, Yang H, Ji W, Wu W, Chen S, Zhang W, et al. Virology, epidemiology, pathogenesis, and control of COVID-19. Viruses. 2020;12(4):372.

10. Wrapp D, Wang N, Corbett KS, Goldsmith A, Hsieh CL, Abiona O, et al. Cryo-EM structure of the 2019-nCoV spike in the prefusion conformation. Science. 2020;367(6483):1260-3.
11. Xia H, Lazartigues E. Angiotensin-converting enzyme 2 in the brain: properties and future directions. I Neurochem. 2008;107(6):1482-94.

12. Wan S, Yi Q, Fan S, Lv J, Zhang X, Guo L, et al. Characteristics of lymphocyte subsets and cytokines in peripheral blood of 123 hospitalized patients with 2019 novel coronavirus pneumonia (NCP). MedRxiv. 2020. doi: https://doi. org/10.1101/2020.02.10.20021832.

13. Lahiri D, Ardila A. COVID-19 pandemic: a neurological perspective. Cureus. 2020;12(4):e7889.

14. Mao L, Jin H, Wang M, Hu Y, Chen $S$, He Q, et al. Neurologic manifestations of hospitalized patients with coronavirus disease 2019 in Wuhan, China. JAMA Neurol. 2020;77(6):1-9.

15. Chen T, Wu D, Chen H, Yan W, Yang D, Chen G, et al. Clinical characteristics of 113 deceased patients with coronavirus disease 2019: retrospective study. BMJ. 2020;368:m1091.

16. AHA/ASA Stroke Council Leadership. Temporary emergency guidance to US stroke centers during the COVID-19 pandemic: On Behalf of the American Heart Association/American Stroke Association Stroke Council Leadership. Stroke. 2020;51(6):1910-2.

17. Yang $X, Y u Y, X u \mid$, Shu $H$, Xia J, Liu $H$, et al. Clinical course and outcomes of critically ill patients with SARS-CoV-2 pneumonia in Wuhan, China: a single-centered, retrospective, observational study. Lancet Respir Med. 2020;8(5):475-81.

18. Rabaan AA, Al-Ahmed SH, Haque S, Sah R, Tiwari R, Malik YS, et al. SARSCoV-2, SARS-CoV, and MERS-COV: a comparative overview. Infez Med. 2020;28(2):174-84.

19. Acar T, Demirel EA, Afşar N, Akçalı A, Demir GA, Alagöz AN, et al. Nörolojik bakış açısından COVID-19. Turk | Neurol. 2020;26:56-106. 